\title{
Checklist of spiders and opiliones (Arachnida Araneae, Opiliones) of Sicilian southest swamp lakes "Pantano Cuba", "Pantano Longa- rini" and "Pantano Bruno" (Italy). Fifth contribution to knowledge of Sicilian spider fauna
}

\author{
Antonino Denticil,* \& Paolo Galasso² \\ ${ }^{1}$ Via Enrico Cialdini 2, 90124 Palermo, Italy; e-mail: a.dentici@virgilio.it \\ ${ }^{2}$ Stiftung Pro Artenvielfalt $\AA$, Meisenstraße 65, 33607 Bielefeld, Germany; e-mail: paolo_galasso@hotmail.com \\ ${ }^{*}$ Corresponding author
}

\begin{abstract}
We present a first checklist of Araneae and Opiliones of Pantano Bruno, Pantano Cuba and Pantano Longarini, swamp lakes which are part of one of the most important Sicilian wetland, never studied before for this group of arthropoda, located in the southeast coast of Sicily, between Ispica (Ragusa) and Pachino (Syracuse). From March 2016 until February 2021 samples and data were collected on the field, investigating different types of habitat. In total, 98 different species belonging to 86 genera and 27 families of spiders were found in the area, plus 3 species of 2 genera and 1 families of opilions. The checklist includes interesting first sicilian records of Cyrtarachne ixoides (Simon, 1870) (Araneidae), Crustulina guttata (Wider, 1834) (Theridiidae), Eratigena fuesslini (Pavesi, 1873) (Agelenidae), Nurscia albomaculata (Lucas, 1846) (Titanoecidae) and Tibellus maritimus (Menger, 1875) (Philodromidae). Additional biological, distribution and chorotype information are indicated for each of the new records.
\end{abstract}

KEY WORDS Arachnids; Araneofauna; Sicily; Stiftung Pro Artenvielfalt; Wetland.

Received 22.03.2021; accepted 16.07.2021; published online 14.09.2021

\section{INTRODUCTION}

Currently, 1583 species of spiders are reported for Italy, represented by a total of 51 families and 474 genus (Netwing, 2021). The richest region in species is actually Trentino AltoAdige, north of Italy, with 831 species and the major islands Sardinian and Sicily, for which are up to date respectively reported 522 species (44 families and 245 genus) and 428 species (44 families and 201 genus) (Pantini \& Isaia, 2019). As regards the Opiliones, 134 species are reported for Italy, represented by 44 genus and 11 families, of which only 19 species, 17 genus and 6 families for Sicily (Pantini \& Isaia, 2019). All the surveys carried out over the time have been showing an ever increasing number of species for this region, (Dentici, 2017; Dentici \& Amata, 2018; Schifani et al., 2019; Dentici, 2019; Bolognin et al., 2021; Dentici \& Amata, 2021; Dentici et al., 2021): if on the one hand this is the result of a deeper and wider field research, on the other hand is partly the consequence of a constant change of Mediterranean araneofauna.

This paper represents a contribution to the current knowledge of Mediterranean and Italian spiders and opiliones, as well as a remarkable update of the Sicilian checklist. 


\section{MATERIAL AND METHODS}

\section{Study area}

A focused survey on spiders and opiliones was conducted at the swamp lakes named "Pantano Bruno" (36 41'56.36”N, 1458'59.12”'E), “Pantano Longarini" (36 $\left.46^{\circ} 42.41^{\prime \prime} \mathrm{N}, 15^{\circ} 00^{\prime} 25.97^{\prime \prime} \mathrm{E}\right)$ and “Pantano Cuba" (3642'26.20”N, 15 1'38.70”E), in the southeast coast of Sicily, near Ispica and Pachino, respectively in the Ragusa and Siracusa provinces (Fig. 1).

These three coastal swamp lakes, which extend in total for no less than 350 hectares, are part of the most important southernmost Italian wetlandcomplex as well as one of the most important coastal wetland of southern Europe. Together with others smaller swamp lakes located along the southern coastline (named, from East to West, Ponterio, Ciaramiraro, Baronello, Auruca, Cannone, Gorgo Salato), the whole wetland-complex is included in Natura 2000 as Special Areas of Conservation (SACs ITA090003) and Special Protection Areas (SPAs ITA090029), designated respectively under the Habitats Directive (Directive 92/43/EEC of 21 May 1992) and the Birds Directive (Directive
79/409/EEC of 2 April 1979 and 2009/147/EC of 30 November 2009). Due to their great relevance for the Mediterranean biodiversity and their peculiar flora and fauna, Pantano Cuba and Pantano Longarini were purchased, starting from 2013, by the German foundation "Stiftung Pro Artenvielfalt (®) - Foundation Pro Biodiversity, which is specialized on biodiversity protection and conservation, for a total of about 380 hectares. The same foundation promoted this survey. Pantano Bruno, Pantano Cuba and Pantano Longarini are dynamic habitats characterized by shallow, brackish and standing waters, surrounded by a variable and diversified vegetation and habitats. Because of the short distance between them (Pantano Bruno is only $1.5 \mathrm{~km}$ away from Pantano Longarini and $3 \mathrm{~km}$ away from Pantano Cuba), the three lakes are in this study considered as a single study area.

Despite of the remarkable biodiversity richness of this area, the most of the updated scientific studies and monitoring projects were focused on avifauna (Galasso et al., 2021) and, only recently, on some groups of arthropoda, such as dragonflies (Galasso et al., 2016; Galasso et al., 2020), but never before on spiders and opiliones.

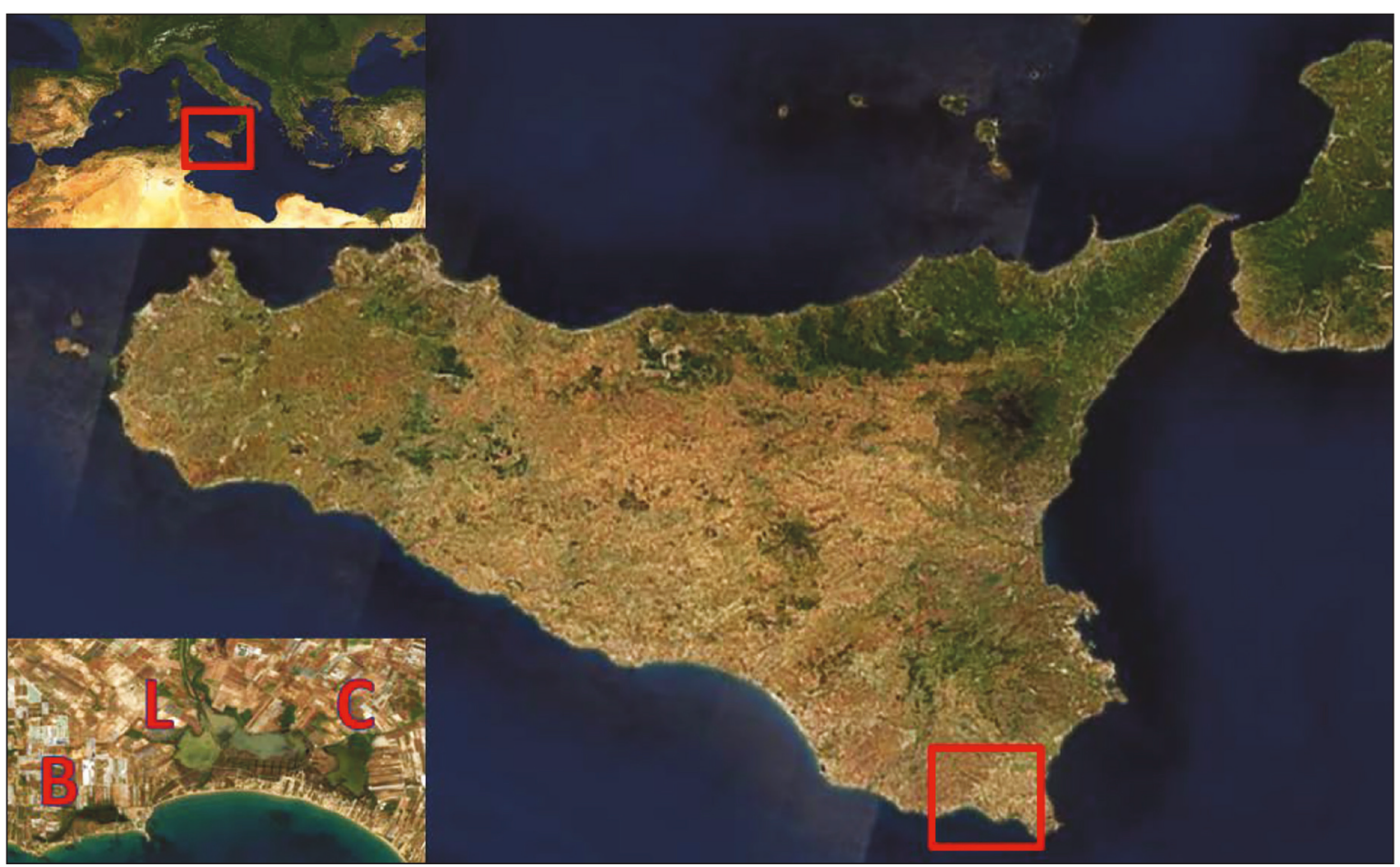

Figure 1. Geographical location of the study area: Pantano Bruno (B), Pantano Longarini (L) and Pantano Cuba $(\mathrm{C})$, in the southeastern coast of Sicily, Italy. 


\section{Sampling methods}

All samples, both spiders and opiliones, have been collected directly on sight on vegetation, old rural buildings, under stones or from their webs by hand or using an entomological sweep net, in many different habitats such as open meadows, uncultivated fields, fruit gardens, edges of canals, Mediterranean scrub, ecotones, etc... Some species were also sampled using pitfall traps and part of them were in addition photographed in nature using a professional digital camera.

Collection of samples and data started in March 2016 to proceed regularly until February 2021, but mainly focused on January-September 2020, with a more systematic and intensified collection.

At least one adult specimen has been observed under a stereomicroscope for a correct determination, for most of the species recorded.

All samples were preserved and transported in centrifuge tubes of different sizes and fixed in $75 \%$ ethanol (Levi, 1977); they are actually stored in the collection of one of the authors (Dentici A.). Classification, taxonomy and distribution in Sicily, follow Roberts (1995), Trotta (2004), Pantini \& Isaia (2019) and World Spider Catalog (2020).

\section{RESULTS}

In total, 98 different species (4 sp., 1 cfr) belonging to 86 genera and 27 families of spiders were found: among these, 5 species and 3 genera are reported for the first time in Sicily, and thus marked by (*) in the checklist below (Table 1). In addition, 3 species of 2 genera and 1 families of Opilions are also reported.

\section{Checklist of spiders and opiliones of Sicilian southest swamp lakes}

The presence of the species is specified by a letter at the end of the species name, after the author: Pantano Cuba (C), Pantano Longarini (L) and Pantano Bruno (B).

Ordo ARANEAE Clerck, 1757

Familia AGELENIDAE C.L. Koch, 1837

Eratigena Bolzern, Burckhardt et Hänggi, 2013

*Eratigena fuesslini (Pavesi, 1873) - C
Lycosoides Lucas, 1846

Lycosoides coarctata (Dufour, 1831) - L - C

Textrix Sundevall, 1833

Textrix caudata L. Koch, 1872 - C

Familia AMAUROBIIDAE Thorell, 1870

Amaurobius C.L. Koch, 1837

Amaurobius erberi (Keyserling, 1863) - L

Familia ARANEIDAE Clerck, 1757

Aculepeira Chamberlin et Ivie, 1942

Aculepeira armida (Audouin, 1826) - C

Araneus Clerck, 1757

Araneus angulatus Clerck, 1757 - C

Araniella Chamberlin et Ivie, 1942

Araniella sp. - L

Argiope Audouin, 1826

Argiope trifasciata (Forsskål, 1775) - L - C- B

Cyclosa Menge, 1866

Cyclosa conica (Pallas, 1772) - L

Cyclosa insulana (Costa, 1834) - L - C- B

*Cytarachne Thorell, 1868

*Cyrtarachne ixoides (Simon, 1870) - L - B

Larinioides Caporiacco, 1934

Larinioides cornutus (Clerck, 1757) - L - C

Larinioides suspicax (O. Pickard-Cambridge, 1876)

- L - C- B

Lipocrea Thorell, 1878

Lipocrea epeirodes (O.Pickard-Cambridge, 1872) - L

Neoscona Simon, 1846

Neoscona subfusca (C.L. Koch, 1837) - C

Zilla C.L. Koch, 1836

Zilla diodia (Walckenaer, 1802) - L - C

Zygiella F.O. Pickard-Cambridge, 1902

Zygiella $\boldsymbol{x}$-notata (Clerck, 1757) - L - C - B

Familia CHEIRACANTHIIDAE Wagner, 1887

Cheiracanthium C.L. Koch, 1839

Cheiracanthium angulitarse Simon, 1878 - L - C

Cheriacanthium mildei L. Koch, 1864 - C 
Familia CLUBIONIDAE Wagner, 1887

Porrhoclubiona Lohmander, 1944

Phorroclubiona sp. - C

Familia DICTYNIDAE O.Pickard-Cambridge, 1871

Brigittea Lehtinen, 1967

Brigittea civica (Lucas, 1850)

Familia DYSDERIDAE C.L. Koch, 1837

Dysdera Latreille, 1804

Dysdera crocata C.L. Koch, 1838 - L - C- B

Familia FILISTATIDAE Ausserer, 1867

Filistata Latreille, 1810

Filistata insidiatrix (Forsskål, 1775) - L - C- B

Familia GNAPHOSIDAE Pocock, 1898

Drassodes Westring, 1851

Drassodes sp. - L

Echemus Simon, 1878

Echemus angustifrons (Westring, 1861) - L

Gnaphosa Latreille, 1804

Gnaphosa montana (L. Koch, 1866) - C

Nomisia Dalmas, 1921

Nomisia aussereri (L. Koch, 1872) - L - C

Poecilochroa Westring, 1874

Poecilochroa furcata Simon, 1914 - C

Familia LINYPHIIDAE Blackwall, 1859

Araeoncus Simon, 1884

Araeoncus humilis (Blackwall, 1841) - L

Frontinellina van Helsdingen, 1969

Frontinellina frutetorum (C.L. Koch, 1835) - L - C- B

Linyphia Latreille, 1804

Linyphia triangularis (Clerck, 1757) - L

Microlinyphia Gerhardt, 1928

Microlinyphia pusilla (Sundevall, 1830) - C

Tenuiphantes Saaristo et Tanasevitch, 1996

Tenuiphantes herbicola (Simon, 1884) - C

Trichoncus Simon, 1884

Trichoncus aurantiipes Simon, 1844 - L
Familia LYCOSIDAE Sundevall, 1833

Alopecosa Simon, 1885

Alopecosa albofasciata (Brullé, 1832) - L - C - B

Arctosa C.L. Koch, 1847

Arctosa fulvolineata (Lucas, 1846) - C

Arctosa cfr lacustris (Simon, 1876) - L

Hogna Simon, 1885

Hogna radiata (Latreille, 1817) - L - C - B

Pardosa C.L. Koch, 1847

Pardosa proxima (C.L. Koch, 1847) - C

Trabea Simon, 1876

Trabea paradoxa Simon, 1876 - C

Trochosa C.L. Koch, 1847

Trochosa ruricola (De Geer, 1778) - L - C

Trochosa terricola Thorell, 1856 - C

Familia MITURGIDAE Simon, 1886

Zora C.L. Koch, 1847

Zora manicata Simon, 1878 - L - C

Familia OECOBIIDAE Blackwall, 1862

Oecobius Lucas, 1846

Oecobius navus Blackwall, 1859 - L - C

Familia PHILODROMIDAE Thorell, 1870

Philodromus Walckenaer, 1826

Philodromus margaritatus (Clerck, 1757) - B

Pulchellodromus Wunderlich, 2012

Pulchellodromus glaucinus (Simon, 1870) - L - C

Thanatus C.L.Koch, 1837

Thanatus vulgaris Simon, 1870 - L

Tibellus Simon, 1875

*Tibellus maritimus (Menge, 1875) - L - C

Familia PHOLCIDAE C.L. Koch, 1850

Holocnemus Simon, 1875

Holocnemus pluchei (Scopoli, 1763) - C

Pholcus Walckenaer, 1805

Pholcus phalangioides (Fuesslin, 1775) - L - C

Familia PISAURIDAE Simon, 1890

Pisaura Simon, 1886

Pisaura sp. - C 
Familia SALTICIDAE Blackwall, 1841

Attulus Simon, 1889

Attulus pubescens (Fabricius, 1775) - C

Chalcoscirtus Bertkau, 1880

Chalcoscirtus infimus (Simon, 1868) - C - B

Cyrba Simon, 1876

Cyrba algerina (Lucas, 1846) - L - C - B

Evarcha Simon, 1902

Evarcha jucunda (Lucas, 1846) - L - C - B

Hasarius Simon, 1871

Hasarius adansoni (Audouin, 1826) - C

Heliophanus C.L. Koch, 1833

Heliophanus tribulosus Simon, 1868 - L - B

Icius Simon, 1876

Icius hamatus (C.L. Koch, 846) - C - B

Marpissa C.L. Koch, 1846

Marpissa nivoyi (Lucas, 1846) - C

Menemerus Simon, 1868

Menemerus semilimbatus (Hahn, 1829) - L - C - B

Menemerus taeniatus (L. Koch, 1867) - C

Neaetha Simon, 1884

Neaetha membrosa (Simon, 1868) - C

Phlegra Simon, 1876

Phlegra bresnieri (Lucas, 1846) - L

Pseudicius Simon, 1885

Pseudicius encarpatus (Walckenaer, 1802) - L - C

Salticus Latreille, 1804

Salticus propinquus Lucas, 1846 - L - C - B

Salticus scenicus (Clerck, 1757) - L - B

Salticus zebraneus (C.L. Koch, 1837) - L

Thyene Simon, 1885

Thyene imperialis (Rossi, 1846) - C

Familia SCYTODIDAE Blackwall, 1864

Scytodes Latreille, 1804

Scytodes thoracica (Latreille, 1802) - L - C

Familia SEGESTRIIDAE Simon, 1893

Segestria Latreille, 1804

Segestria bavarica C.L. Koch, 1843 - C
Familia SICARIIDAE Keyserling, 1880

Loxosceles Heineken et Lowe, 1832

Loxosceles rufescens (Dufour, 1820) - L - C

Familia SPARASSIDAE Bertkau, 1872

Micrommata Latreille, 1804

Micrommata ligurina (C.L. Koch, 1845) - L - C

Olios Walckenaer, 1837

Olios argelasius (Walckenaer, 1806) - C

Familia TETRAGNATHIDAE Menge, 1866

Pachygnatha Sundevall, 1823

Pachygnatha degeeri Sundevall, 1830 - L

Tetragnatha Latreille, 1804

Tetragnatha extensa (Linnaeus, 1758) - L - C - B

Tetragnatha obtusa C.L. Koch, 1837 - L - C - B

Familia THERIDIIDAE Sundevall, 1833

Anelosimus Simon, 1891

Anelosimus pulchellus (Walckenaer, 1802) - C

Asagena Sundevall, 1833

Asagena phalerata (Panzer, 1801) - C

Argyrodes Simon, 1864

Argyrodes argyrodes (Walckenaer, 1841) - L - C - B

Crustulina Menge, 1868

*Crustulina guttata (Wider, 1834) - L

Enoplognatha Pavesi, 1880

Enoplognatha mandibularis (Lucas, 1846) - L - B

Euryopis Menge, 1868

Euryopis episinoides (Walckenaer, 1847) - L - C

Kochiura Archer, 1950

Kochiura aulica (C.L. Koch, 1838) - L - C - B

Platnickina Kocak et Kemal, 2008

Platnickina nigropunctata (Lucas, 1846) - C

Steatoda Sundevall, 1833

Steatoda grossa (C.L. Koch, 1838) - L

Steatoda paykulliana (Walckenaer, 1806) - C

Steatoda triangulosa (Walckenaer, 1802) - L - C - B

Theridion Walckenaer, 1805

Theridion mystaceum C.L. Koch, 1870 - C 
Familia THOMISIDAE Sundevall, 1833

Monaeses Thorell, 1869

Monaeses paradoxus (Lucas, 1846) - L - C

Platnickina Kocak et Kemal, 2008

Platnickina nigropunctata (Lucas, 1846) - B

Runcinia Simon, 1875

Runcinia grammica (C.L. Koch, 1837) - L - C - B

Synema Simon, 1864

Synema globosum (Fabricius, 1775) - L - C - B

Thomisus Walckenaer, 1805

Thomisus onustus Walckenaer, 1805 - L - C - B

Xysticus C.L. Koch, 1835

Xysticus bufo Simon, 1820 - L - C

Familia TITANOECIDAE Lehtinen, 1967

*Nurscia Simon, 1874

*Nurscia albomaculata (Lucas, 1846) - C

Familia ULOBORIDAE Thorell, 1869

Uloborus Latreille, 1806

Uloborus plumipes Lucas, 1846 - L - C

Familia ZODARIIDAE Thorell, 1881

Zodarion Walckenaer, 1826

Zodarion ludibundum Simon, 1914 - C

Zodarion elegans (Simon, 1873) - L - C

Ordo OPILIONES Sundevall, 1833

Familia PHALANGIIDAE Latreille, 1802

Metaphalangium Roewer, 1911

Metaphalangium abruptum (Roewer, 1911) - L

Metaphalangium cirtanum (C.L. Koch, 1839) - L

- C - B

Opilio Herbst, 1798

Opilio canestrinii (Thorell, 1876) - L - C - B

\section{New records}

For each new Sicilian records (*), "legit" and collection data are below indicated, as well as locality and / or collection site:

Ordo ARANEAE Clerck, 1757
Familia AGELENIDAE C.L.Koch, 1837

Genus Eratigena Bolzern, Burckhardt et Hänggi, 2013

Eratigena fuesslini (Pavesi, 1873)

Material eXAmined. Pachino (Syracuse), Pantano Cuba, 36²'29.9'N 1501'20.1'E, 10.I.2020, 1 , , legit A. Dentici.

DistRIBUTION. Europe, Turkey.

REMARKS. New species for Sicily. The specimen was collected from its web, built among a pile of stones, in an open meadow near to the swamp lake. Several other webs and specimens were observed near to the same location.

Familia ARANEIDAE Clerck, 1757

Genus Cytarachne Thorell, 1868

Cyrtarachne ixoides (Simon, 1870)

Material eXAmined. Ispica (Ragusa), Pantano Bruno, 3641'50.59”'N 1458'53.80”'E, 12.VI.2020, 1 \&, legit P. Galasso; Pachino (Syracuse), Pantano Longarini, 36²'31.65' $\mathrm{N} 15^{\circ} 1^{\prime} 8.60^{\prime \prime} \mathrm{E}, 20 . \mathrm{II} .2021$, 1 , , legit P. Galasso.

Distribution. Mediterranean, Caucasus, Madagascar.

REMARKS. New genus and new species for Sicily. The specimen was found and collected on a Pistacia lentiscus L.

Familia PHILODROMIDAE Thorell, 1870

Genus Tibellus Simon, 1875

Tibellus maritimus (Menge, 1875)

Material EXAmined. Pachino (Syracuse), Pantano Cuba, 36²'32.2'N 1501'20.3”E, 18.I.2020, 1 § subadult, legit A. Dentici; Pachino (Syracuse), Pantano Longarini, 36²'15.3”N 1459'58.0”'E, 01.VII.2020, 2 +, legit P. Galasso.

Distribution. Global distribution (WSC, 2021), including North America, Europe, Caucasus, Russia (Europe to Far East), Central Asia and China.

REMARKS. New genus for Sicily, already found in Monte Pellegrino (Dentici, in press) and new species. The specimens were collected on top of halophilic vegetation. 
Familia THERIDIIDAE Sundevall, 1833

Genus Crustulina Menge, 1868

\section{Crustulina guttata (Wider, 1834)}

Material examined. Ispica (Ragusa), Pantano Longarini (Mouth), 36²'15.3”N 14'59'58.0”E, 15.I.2020, 1 q, legit A. Dentici.

Distribution. Canary Islands, Europe, Caucasus, Russia (Europe to South Siberia), Central Asia, China, Korea, Japan.

REMARKS. New species for Sicily; collected on its web, built on low herbaceous vegetation. It has been bred and observed: on 25.II.2020 it made a moult, probably the last one before sexual maturation, as on 20.V.2020 it produced a cocoon, and on 26.V.2020 a second one, but $1 / 3$ in size compared to the first. The reason of non-fertile eggs production has not been clarified. It did not show any kind of parental care, cocoons are like an accessory of the tangle web, characteristic of the Theridiidae family.
Familia TITANOECIDAE Lehtinen, 1967

Genus Nurscia Simon, 1874

Nurscia albomaculata (Lucas, 1846)

Material examined. Pachino (Syracuse), Pantano Cuba, 36 42 '28.67'N 15 1'15.46”'E, 28.V. 2016, 1 ㅇ, legit P. Galasso.

Distribution. Europe, Turkey, from Egypt to Central Asia.

REMARKs. New genus and new species for Sicily; specimen found under a stone and photographed (Figure 2), but not sampled. Considering the well-defined pattern and the distribution of the $N$. albomaculata species, the authors identified it as such. In addition, another specimen (legit Angelo Ditta) was sampled in Mazara del Vallo (TP) on 5.1.2021, which confirms the identification made by photography.
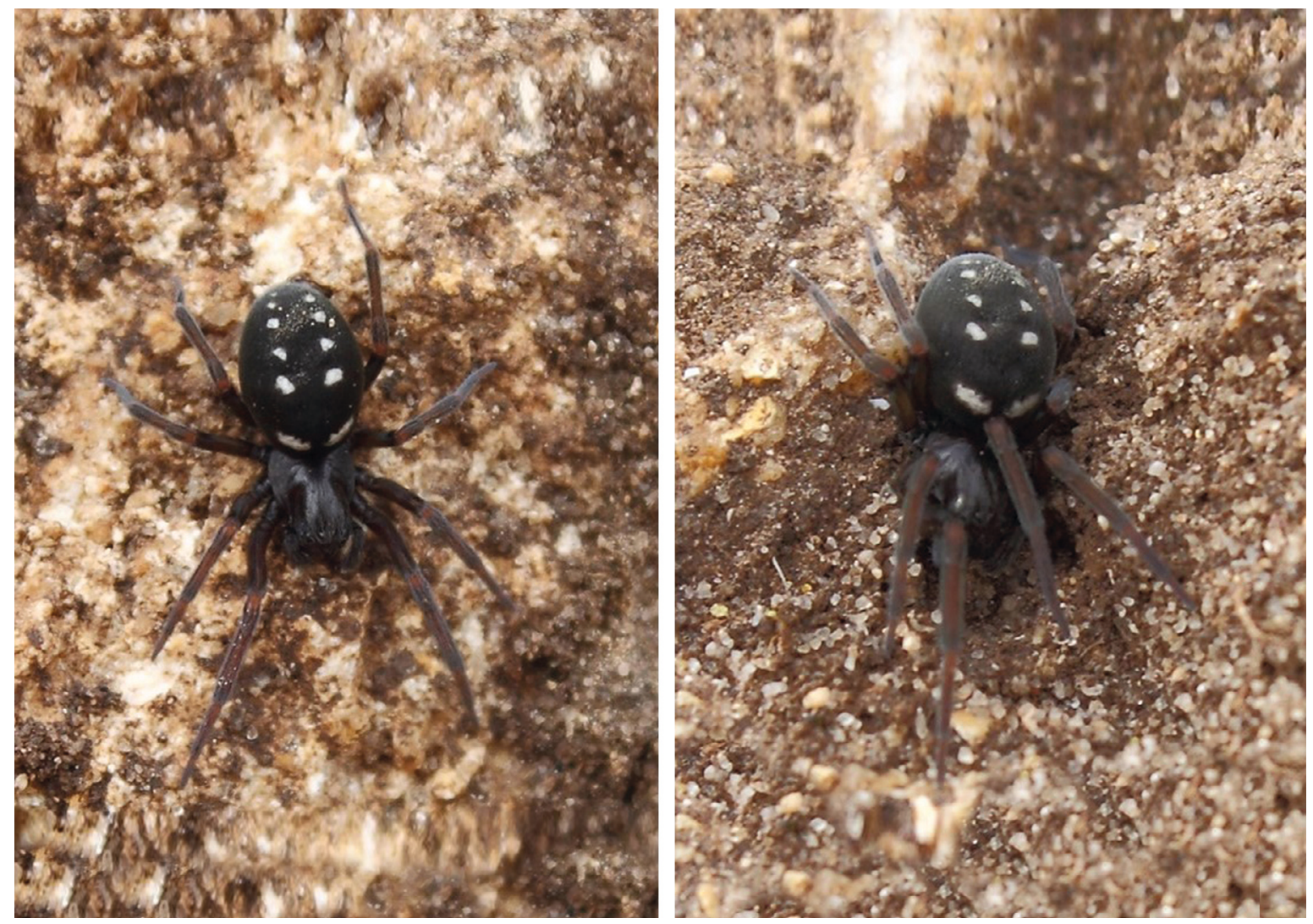

Figure 2. Nurscia albomaculata photographed in Pantano Cuba on 25.V.2016 (photo by P. Galasso). 


\section{DISCUSSION}

Collected data show a rich spider community for this wetland, considering the relatively short time of this preliminary study. It is mainly represented by families of Salticidae (18\% of the total species), Araneidae (14\%) and, secondly, by Theridiidae (12\%) and Lycosidae (8\%). All the others families are poorly represented, often with only 1-3 species per family (Fig. 3). Obviously, all the percentages of different families are purely indicative and closely related to the examined material into the limits of the work carried out. Furthermore, please note that several families, such as Sicariidae, are monospecific in our territory, as well as families as Salticidae and Theridiidae are instead well represented with many genera and species. Furthermore, mostly crepuscular or nocturnal spiders, not well-represented in the checklist, are probably "escaped" from sampling activities, therefore, the results only show the main families and species actually sampled and identified and does not want to be a study on the intraspecific abundance of different species.
Despite this, as a consequence of the data collected thanks to this survey, the actual number of Sicilian spiders reported in the available bibliography and equal to 428 species, including 44 families and 201 genus (Pantini \& Isaia, 2019) can be definitively updated to 433 , including 44 families and 204 genus.

An extension of this survey, for such a rich and important area for Mediterranean biodiversity, would certainly provide additional interesting data and, why not, probably additional new Sicilian records, thus contributing to the further expansion of regional knowledge of spiders and opiliones.

\section{ACKNOWLEDGMENTS}

We want to thank our colleagues Giancarlo Torre and Adele Schittone, for giving their contribution to specimens sampling and transporting, to Franco Ciro Amata for making his sample available to us, to Nino Patti, Giuseppe Lo Bianco and Valeria Lo Bianco for supporting and helping sampling and its logistics. A special thanks goes to Paolo Pantini,

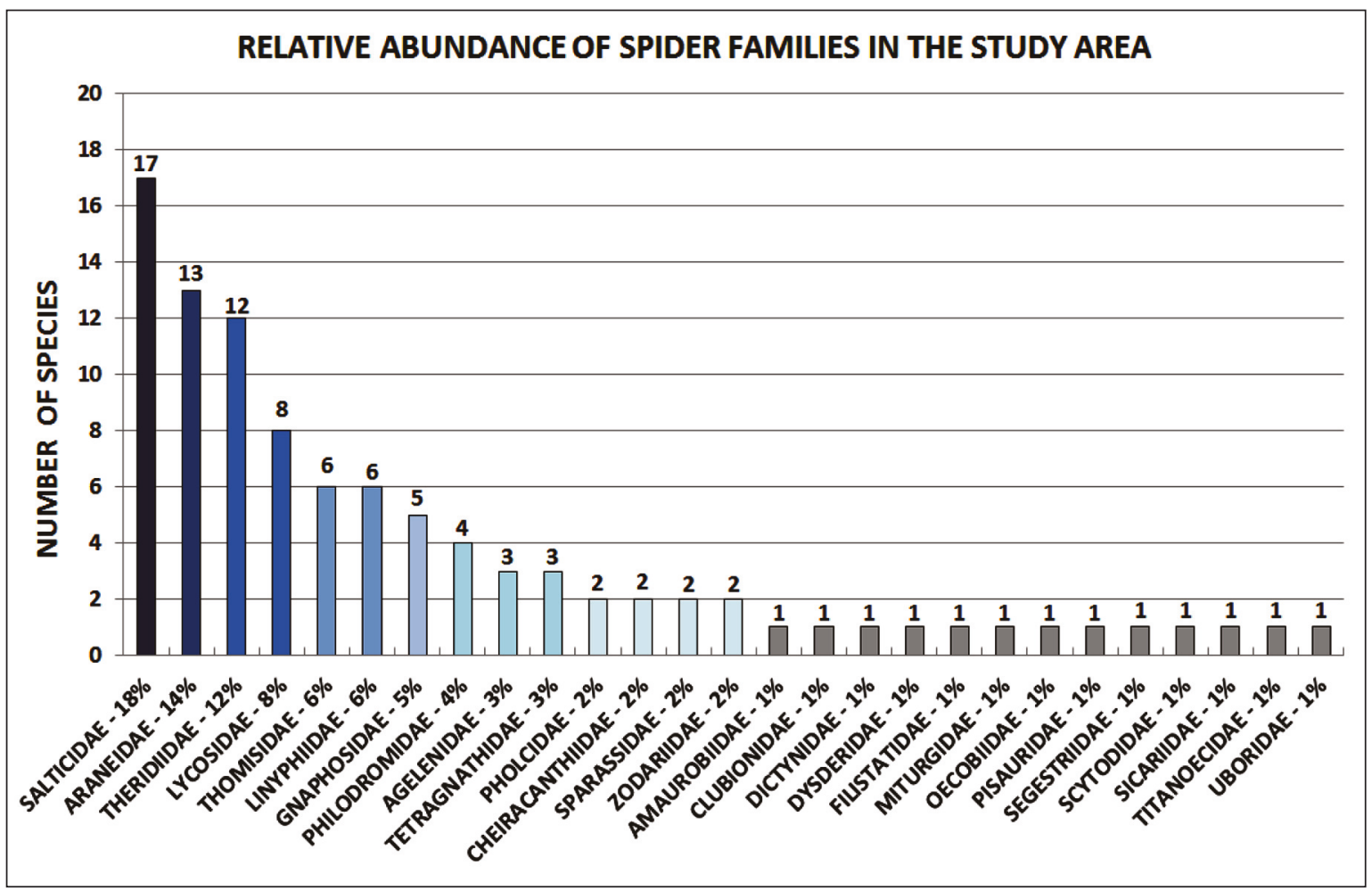

Figure 3. Structure of the spider community of the study area on a total of 98 species and 27 related families recorded. 
for his constant and professional availability. We also want to express our gratitude to the German foundation "Stiftung Pro Artenvielfalt" for promoting and supporting the biodiversity conservation and believing in the value of scientific research at the service of a better world.

\section{REFERENCES}

Dentici A., 2017. Contribution to the knowledge of Sicilian spider fauna (Arachnida Araneae). Biodiversity Journal, 8: 861-864.

Dentici A. \& Amata F.C., 2018. New faunistic data for the Sicilian Aracnofauna (Arachnida Araneae). Biodiversity Journal, 9: 271-276.

Dentici A., 2019. Third contribution to the knowledge of Sicilian spider fauna (Arachnida Araneae). Biodiversity Journal, 10: 117-120.

https://doi.org/10.31396/Biodiv.Jour.2019.10.2.117.120

Dentici A., Galasso P. \& Barbera A., 2021. First record of Trichoncus aurantiipes Simon, 1884 (Araneae Linyphiidae) in Italy. Biodiversity Journal, 12: 125-128. https://doi.org/10.31396/Biodiv.Jour.2021.12.1.125.128

Dentici A. \& Amata F.C., 2021. Prodidomus amaranthinus (Lucas, 1846) (Araneae Gnaphosidae) new for the Italian araneofauna. Biodiversity Journal, 12: 357-359. https://doi.org/10.31396/Biodiv.Jour.2021.12.2.357.359

Dentici A. (in press.). Araneofauna (Arachnida Araneae) of Monte Pellegrino (Sicily, Italy): Fourth contribution to knowledge of the Sicilian spider fauna. Biodiversity Journal.

Bolognin L., Moretto E., Devincenzo U. \& Guariento L.A., 2021. First record of Neoscona byzanthina (Pavesi, 1876) (Arachnida Araneae) from Italy. Biodiversity Journal, 12: 17-19. https://doi.org/10.31396/Biodiv.Jour.2021.12.1.17.19

Galasso P., Curcuraci N. \& Marletta A., 2016. First record of Brachytron pratense (Müller, 1764) in Sicily (Odonata Aeshnidae). Biodiversity Journal, 7: 51-54.

Galasso P., Marletta A. \& Corso A., 2020. Odonata of Sicilian southeast swamp lakes "Pantano Cuba" and "Pantano Longarini" (SE-Sicily, Italy). Biodiversity Journal, 11: 57-64. https://doi.org/10.31396/Biodiv.Jour.2020.11.1.57.64

Galasso P., Cappuzzello C., Gambino E., Torre G., Galasso G. \& Patti N., 2021. Avifauna of "Sicilian southeast swamp lakes" and surroundings areas (Ragusa and Syracuse, Sicily) with commented records of interest. Biodiversity Journal, 12: 441-462.

https://doi.org/10.31396/Biodiv.Jour.2021.12.2.441. 462

Levi H.W., 1966. The Care of Alcoholic Collections of Small Invertebrates. Systematic Zoology, 15: 183-188.

Marcellino I., 1970. Su alcuni Opilioni (Arachnida) della Sicilia sud-orientale e centrale. Bollettino delle sedute dell'Accademia Gioenia di Scienze Naturali (serie 4), 10: 283-308.

Marcellino I., 1973. Opilioni delle isole Eolie ed Egadi. Lavori della Società Italiana di Biogeografia 3: 327339.

Marcellino I., 1974. Nuovi dati sugli opilioni (Arachnida) di Sicilia e di altre isole del Mediterraneo. Animalia 1: 185-200.

Marcellino I.I., 1975. Considérations biogéographiques sur les Opil-ions de Sicile.InL. Vlijm (ed.), Proceedings of the 6th International Arachnological Congress. Amsterdam: Nederlandse Entomologische Vereniging: 222-226.

Nentwig W., Blick T., Bosmans R., Gloor D., Hänggi A. \& Kropf C., 2020. Araneae - spiders of Europe. Version 2.2021. Internet: http://www.araneae.unibe.ch (25.Feb. 2021).

Pantini P. \& Isaia M., 2019. Araneae.it: the online Catalog of Italian spiders with addenda on other Arachnid Orders occurring in Italy (Arachnida: Araneae, Opiliones, Palpigradi, Pseudoscorpionida, Scorpiones, Solifugae). Fragmenta Entomologica, 51: 127-152. Online at www.araneae.it.

Roberts M.J., 1995. Spiders of britain and Northern Europe. Harper Collins, London, 383 pp.

Schifani E., Dentici A., Alleruzzo L. \& Di Pompeo P., 2019. Spermophora senoculata on Sicily/Italy (Araneae: Pholcidae). Arachnologische Mitteilungen 58: 6-8. https://doi.org/10.30963/aramit5803

Staręga W., 2004. On some species of Metaphalangium Roewer from the Mediterranean Region (Opiliones, Phalangiidae). Revista Ibérica de Aracnologia 9: 239-240.

Trotta A., 2004. Introduzione ai Ragni italiani (Arachnida Araneae). Memorie della Società Entomologica Italiana, 83: 3-178.

World Spider Catalog, 2020. World Spider Catalog. Version 21.5. Natural History Museum Bern, online at http://wsc.nmbe.ch, accessed on 20/09/2020. https://doi.org/10.24436/2 
